\title{
Rekam Jejak Kinerja Crew Sebagai Model Sistem Pendukung Keputusan Pengangkatan Leader
}

\author{
Yan Yang Thanri \\ Fakultas Teknik dan Ilmu Komputer, Sistem Informasi, Universitas Potensi Utama, Medan, Indonesia \\ Email: ythanri@gmail.com
}

\begin{abstract}
Abstrak-Sumber daya manusia kompetitif adalah karyawan yang dapat bekerja secara produktif dan professional untuk ketercapaian Visi, Misi dan Tujuan dari perusahaan tersebut. Untuk mendapatkan sumber daya manusia yang kompetitif dilihat dari kualitas kinerja karyawan tersebut. Kualitas kinerja karyawan terekam dalam rekam jejak kinerja karyawan yang memiliki peranan penting bagi perusahaan dalam pengambilan keputusan dalam meningkatkan Sumber daya manusia perusahaan. Sumatera Utara khususnya kota medan banyak perusahaan yang bergerak di bidang family entertainment center, hasil pengamatan yang telah dilakukan kepada beberapa perusahaan yang bergerak dibidang ini, umumnya dalam hal pengangkatan Leader masih menggunakan seniority system dan spoil system. Dampak yang ditimbukan dari seniority system adalah tidak menjamin kompetensi yang dimiliki oleh seorang karyawan dan belum tentu mampu memangku jabatan tersebut, dampak dari spoil system adalah promosi yang didasarkan pada kekeluargaan, sistem ini kurang baik karena didasarkan pada pertimbangan suka atau tidak suka. untuk mengatasi hal tersebut diatas maka diperlukan sebuah sistem rekam jejak kinerja crew sebagai model sistem pendukung keputusan untuk pengangkatan leader dengan melibatkan faktor merit system, seniority system dan leadership. Model Sistem Pendukung Keputusan tersebut akan menggunakan metode Analytical Hierarchy Process (AHP) dan Simple Additive Weighting (SAW). AHP adalah metode yang akan digunakan untuk melakukan perbandingan antara kriteria untuk mendapatkan bobot kriteria sedangkan SAW adalah metode yang digunakan untuk mencari penjumlahan terbobot dari hasil metode AHP dari rating kinerja pada semua alternative dari setiap atribut untuk memberikan rekomendasi terhadap pimpinan perusahaan dalam melakukan pemilihan dari crew dan melakukan proses pengangkatan leader.
\end{abstract}

Kata Kunci: Rekam Jejak, Kinerja Crew, Leader, AHP, SAW, Expert Choice

Abstract-Competitive human resources are employees who can work productively and professionally to achieve the vision, mission and goals of the company. To get competitive human resources seen from the quality of the employee's performance. The quality of employee performance is recorded in the track record of employee performance that has an important role for the company in making decisions in improving the company's human resources. North Sumatra, in particular the city of Medan, many companies engaged in the family entertainment center, the results of observations that have been made to several companies engaged in this field, generally in terms of appointment of Leaders still use the seniority system and spoil system. The impact of the seniority system is not guaranteeing the competency of an employee and not necessarily being able to assume the position, the impact of the spoil system is promotion based on kinship, this system is not good because it is based on consideration of likes or dislikes. To overcome the above, we need a system of track record of crew performance as a model of decision support systems for the appointment of leaders by involving factors of merit system, seniority system and leadership. The decision support system model will use the Analytical Hierarchy Process (AHP) and Simple Additive Weighting (SAW) methods. AHP is a method that will be used to make comparisons between criteria to get criteria weights while SAW is a method used to find the weighted sum of the results of the AHP method of rating performance on all alternatives of each attribute to provide recommendations for company leaders to make the selection of the crew and conduct the process of appointing a Leader.

Keywords: Track Record, Crew Performance, Leader, AHP, SAW, Expert Choice

\section{PENDAHULUAN}

Untuk meningkatkan kinerja perusahaan baik yang bergerak dibidang jasa ataupun manufaktur dimana membuat perusahaan dapat bersaing baik ditingkat regional, nasional bahkan internasional dengan memiliki Sumber Daya Manusia (SDM) yang kompetitif [1]. SDM kompetitif adalah karyawan yang dapat bekerja secara produktif dan professional untuk ketercapaian Visi, Misi dan Tujuan dari perusahaan tersebut [2]. Untuk mendapatkan SDM yang kompetitif dilihat dari kualitas kinerja karyawan tersebut [3]. Kualitas kinerja karyawan terekam dalam Rekam Jejak Kinerja Karyawan [4], hasil dari Rekam Jejak tersebut adalah berupa hasil penilaian kinerja karyawan yang memiliki peranan penting bagi perusahaan dalam pengambilan keputusan dalam meningkatkan SDM perusahaan tersebut meliputi identifikasi kebutuhan pengembangan pendidikan, pelatihan, rekrutmen, seleksi, promosi, mutasi, demosi, reward dan punishment [4].

Sumatera Utara khususnya kota medan banyak perusahaan yang bergerak di bidang family entertainment center. Perusahaan ini memiliki lebih dari 74 outlet yang tersebar diseluruh kota besar di Indonesia. Setiap outlet memiliki karyawan yang disebut dengan crew. Setiap outlet akan dipimpin oleh 2 sampai dengan 3 leader. Dari hasil pengamatan yang telah dilakukan kepada beberapa perusahaan yang bergerak dibidang ini, umumnya dalam hal pengangkatan Leader masih menggunakan seniority system dan spoil system, dikarenakan atas dasar menghemat waktu, mudah dan cara yang tidak menyakitkan dalam membuat sebuah keputusan promosi. Sementara dampak yang ditimbukan dari seniority system adalah tidak menjamin kompetensi yang dimiliki oleh seorang karyawan dan belum tentu mampu memangku jabatan tersebut[5], dampak dari spoil system adalah promosi yang didasarkan pada kekeluargaan, sistem ini kurang baik karena didasarkan pada pertimbangan suka atau tidak suka [6]. 
Berdasarkan hal tersebut diatas maka untuk mengatasi hal tersebut diatas maka diperlukan sebuah sistem rekam jejak kinerja crew sebagai model sistem pendukung keputusan untuk pengangkatan leader dengan melibatkan faktor merit system, seniority sistem dan leadership, dimana merit system adalah mutasi karyawan bersifat ilmiah, objektif dan kemampuan kerja [6], seniority sistem dilihat berdasarkan Masa kerja, usia dan pengalaman kerja dan leadership adalah dilihat dari seorang pemimpin dengan segala kemampuan dan intelektual yang mumpuni [7].

Model Sistem Pendukung Keputusan tersebut akan menggunakan metode Analytical Hierarchy Process (AHP) dan Simple Additive Weighting (SAW). AHP adalah metode yang akan digunakan untuk melakukan perbandingan antara kriteria untuk mendapatkan bobot kriteria [8] sedangkan SAW adalah metode yang digunakan untuk mencari penjumlahan terbobot dari hasil metode AHP dari rating kinerja pada semua alternative dari setiap atribut [9] untuk memberikan rekomendasi terhadap pimpinan perusahaan dalam melakukan pemilihan dari crew dan melakukan proses pengangkatan Leader.

\section{METODE PENELITIAN}

Metode penelitian dalam rekam jejak kinerja crew sebagai model sistem pendukung keputusan untuk pengangkatan leader dapat dilihat pada gambar 1.

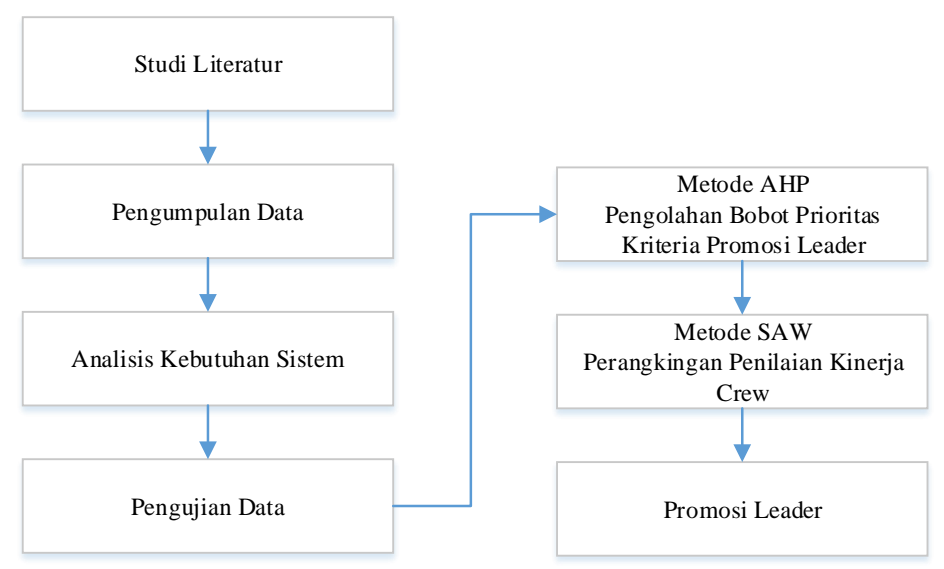

Gambar 1. Metode Penelitian Rekam Jejak Kinerja Crew Sebagai Model Sistem Pendukung Keputusan Pengangkatan Leader

Tahap studi literature adalah mencari bahan referensi yang terkait terhadap Rekam Jejak Kinerja Crew Sebagai Model Sistem Pendukung Keputusan Pengangkatan Leader dengan menggunakan metode Analytical Hierarchy Process (AHP) dan Simple Additive Weighting (SAW). Tahap pengumpulan data dilakukan dengan cara melakukan wawancara dan obeservasi terkait dengan proses penilaian kinerja crew, indicator penilaian kinerja, proses mutase dan promosi dari posisi crew menjadi leader. Tahap analisis kebutuhan sistem adalah menganalisis dan mendata kebutuhan yang digunakan dalam Rekam Jejak Kinerja Crew Sebagai Model Sistem Pendukung Keputusan Pengangkatan Leader, baik secara fisik maupun sistem. Tahap pengujian data yaitu tahap untuk pengolahan data dengan menggunkan metode Analytical Hierarchy Process (AHP) dan Simple Additive Weighting (SAW), dimana AHP digunakan untuk membanding kriteria yang digunakan sebagai indikator pengangkatan leader sehingga mendapat dalam bentuk bobot kriteria sedangkan metode SAW digunakan untuk mendapatkan rekomendasi crew yang layak diangkat menjadi leader dalam bentuk perangkingan. Hasil dari model Sistem Pendukung Keputusan adalah berupa rekomendasi kepada pimpinan untuk pengangkatan Leader.

\subsection{Metode Analytical Hierarchy Process (AHP)}

Prof. Thomas Lorie Saaty mengembang metode AHP pada awal tahun 1970, dimana metode AHP digunakan untuk menentukan urutan perioritas dalam bentuk perangkingan dari berbagai alternative untuk menyelesaikan suatu masalah yang kompleks dan tidak terstruktur dengan cara menstrukturkan dalam bentuk suatu hirarki kriteria [10]. AHP bersifat Resiprocal Comparison, Homogenity, Dependence dan Expectation sebgai landasan aksiomatik [11].

Adapun langkah-langkah penyelesaian masalah dengan metode AHP adalah [12]:

1. Identifikasi masalah dan menentukan solusi dari masalah tersebut.

2. Struktur hirarki yang berupa kriteria-kriteria dan alternative.

3. Matriks perbandingan berpasangan berdasarkan pilihan dari pembuat keputusan dalam bentuk penilaian tingkat kepentingan dari satu elemen dengan elemen yang lain.

4. Normalkan data dengan membagi nilai dari elemen dalam matriks berpasangan pada langkah 3 terhadap total nilai dari kolom.

5. Menghitung nilai eigen vector dan menguji konsistensinya. 
6. Mengulangi langkah 3, 4, dan 5 untuk seluruh tingkat hirarki.

7. Menghitung eigen vector dari setiap matriks perbandingan berpasangan.

8. Menguji konsistensi hirarki.

\subsection{Metode Simple Additive Weighting (SAW)}

Metode penjumlahan bobot atau Simple Additive Weighting (SAW) adalah merupakan bagian dari Multiple Decision Making (MADM) dengan cara menjumlahkan bobot dari rating kinerja pada setiap alternative untuk semua kriteria dengan cara melakukan proses normalisasi matriks keputusan (X) [13].

Adapun langkah-langkah penyelesaian masalah dengan metode SAW adalah [14]:

1. Menentukan alternatif, yaitu Ai.

2. Menentukan kriteria yang akan dijadikan acuan dalam pengambilan keputusan, yaitu $\mathrm{Cj}$.

3. Memberikan nilai rating kecocokan setiap alternatif pada setiap kriteria.

4. Menentukan bobot preferensi atau tingkat kepentingan (W) setiap kriteria.

$\mathrm{W}=[\mathrm{W} 1, \mathrm{~W} 2, \mathrm{~W} 3, \ldots, \mathrm{WJ}]$

5. Membuat tabel rating kecocokan dari setiap alternatif pada setiap kriteria.

6. Membuat matrik keputusan (X) yang dibentuk dari tabel rating kecocokan dari setiap alternatif pada setiap kriteria. Nilai X setiap alternatif (Ai) pada setiap kriteria $(\mathrm{Cj})$ yang sudah ditentukan, dimana, $\mathrm{i}=1,2, \ldots \mathrm{m}$ dan $\mathrm{j}=1,2, \ldots \mathrm{n}$.

$X=\left[\begin{array}{ccc}x_{11} & x_{12} \cdots & x_{1 j} \\ \vdots & & \vdots \\ x_{i 1} & x_{i 2} \cdots & x_{i j}\end{array}\right]$

7. Melakukan normalisasi matrik keputusan dengan cara menghitung nilai rating kinerja ternomalisasi (rij) dari alternatif Ai pada kriteria $\mathrm{Cj}$.

$r_{i j}=\left\{\begin{array}{l}\frac{x_{i j}}{\operatorname{Max} x_{i}\left(x_{i j}\right)} \Rightarrow \text { benefit } \\ \frac{\operatorname{Min}\left(x_{i j}\right)}{x_{i j}} \Rightarrow \text { cost }\end{array}\right.$

8. Hasil dari nilai rating kinerja ternomalisasi (rij) membentuk matrik ternormalisasi (R).

$R=\left[\begin{array}{ccc}r_{11} & r_{12} \cdots & r_{1 j} \\ \vdots & & \vdots \\ r_{i 1} & r_{12} \cdots & r_{i j}\end{array}\right]$

9. Hasil akhir nilai preferensi (Vi) diperoleh dari penjumlahan dari perkalian elemen baris matrik ternormalisasi (R) dengan bobot preferensi (W) yang bersesuaian elemen kolom matrik (W).

$V_{l}=\sum_{j=1}^{n} W_{i} r_{i j}$

Hasil perhitungan nilai Vi yang lebih besar mengindikasikan bahwa alternatif Ai merupakan alternatif terbaik menurut perhitungan metode Simple Additive Weighting.

\section{HASIL DAN PEMBAHASAN}

\subsection{Data Kriteria}

Data kriteria yang tertuang didalam Rekam Jejak Kinerja Crew, dimana penilaian tersebut dijadikan sebagai acuan untukmemberikan rekomendasi kepada pengambil keputusan didalam melakukan proses pemilihan atau mengangkatan Leader oleh pimpinan adalah senority system meliputi usia, masa kerja dan pengalaman sedangkan merit system meliputi ketepatan waktu, kualitas pekerjaan, kecepatan, pengetahuan, tanggung jawab, berpikir strategis, komunikatif, akuntabel, visioner, kerjasama, kreatif dan inovatif dan pendidikan

\subsection{Data Alternatif}

Data alternatif yang digunakan dalam penelitian ini adalah data crew, dimana smapel data crew yang diambil untuk perhitungan dengan menggunakan metode AHP dan SAW sebanyak 5.

\subsection{Model Sistem Pendukung Keputusan}

Model sistem pendukung keputusan dalam rekomendasi pengangkatan leader dengan menggunakan rekam jejak kinerja crew, dimana rekam jejak kinerja crew dilakukan setiap bulan untuk menilai kinerja dari kualitas dan kuantitas seorang crew dalam mengerjakan pekerjaan untuk mencapai visi, misi dan tujuan dari perusahaan tersebut. Adapun flowchart rekam jejak kinerja crew sebagai model sistem pendukung keputusan pengangkatan leader ditunjukkan pada gambar 2. Pada gambar 2 dijelaskan bahwa untuk mendapatkan bobot kreteria untuk mendapatkan rekomendasi Leader adalah dengan melakukan perbandingan berpasangan kemudian dibuat dalam bentuk matrik normalisasi dengan mengju konsistensi hirarki dengan car ajika $\mathrm{CR}<0.1$ maka nilai tersebut bisa dijadikan bobot kriteria, apabila tidak maka harus dilakukan proses perbandingan berpasangan antar kriteria. Penilaian crew dilakukan dengan cara memberikan nilai dalam bentuk rating kecocokan terhadap alternatif untuk 
Available Online at https://ejurnal.stmik-budidarma.ac.id/index.php/mib DOI $10.30865 /$ mib.v4i1.1785

semua kriteria dalam bentuk matrik keputusan (X) dan dinormalisasi (rij) dengan cara melihat apakah atribut tersebut merupakan bagian benefit atau cost sehingga membentuk matrik ternormalisasi (R) kemudian mengalikan bobot kriteria yang dihasilkan dari metode AHP untuk mendapatkan nilai preferensi (Vi) yang ditampilkan dalam bentuk perangkingan untuk promosi leader.

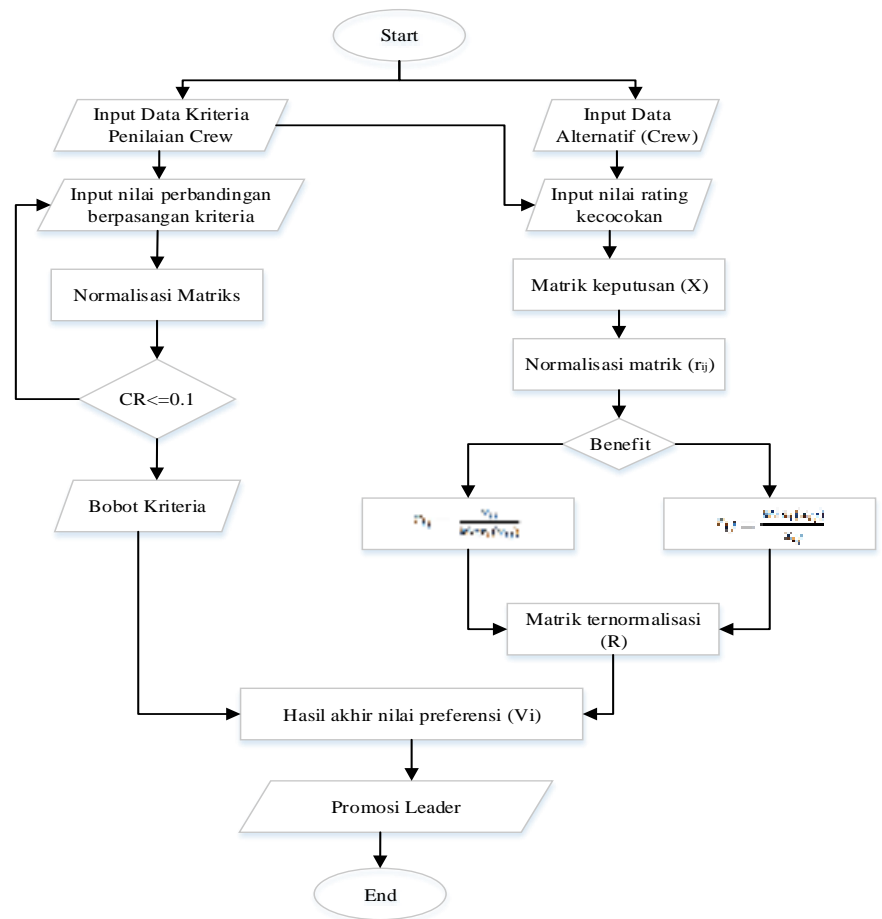

Gambar 2. Flowchart Rekam Jejak Kinerja Crew Sebagai Model Sistem Pendukung Keputusan Pengangkatan Leader

\subsection{Bobot Kriteria pada Rekam Jejak}

Bobot kriteria untuk promosi leader yang terdapat dalam rekam jejak kinerja crew dijadikan sebagai acuan dalam memberikan rekomendasi promosi leader kepada pimpinan perusahaan. Untuk menentukan bobot kriteria dilakukan dengan menggunakan metode Analytical Hierarchy Process (AHP).

a. Input nilai perbandingan berpasangan kriteria

Nilai perbandingan berpasangan didapat dari hasil kuesioner yang telah diberikan kepada pihak perusahaan dalam menilai tingkat kepentingan untuk semua kriteria dengan menggunakan aplikasi expert choice yang ditunjukan pada gambar 3 .

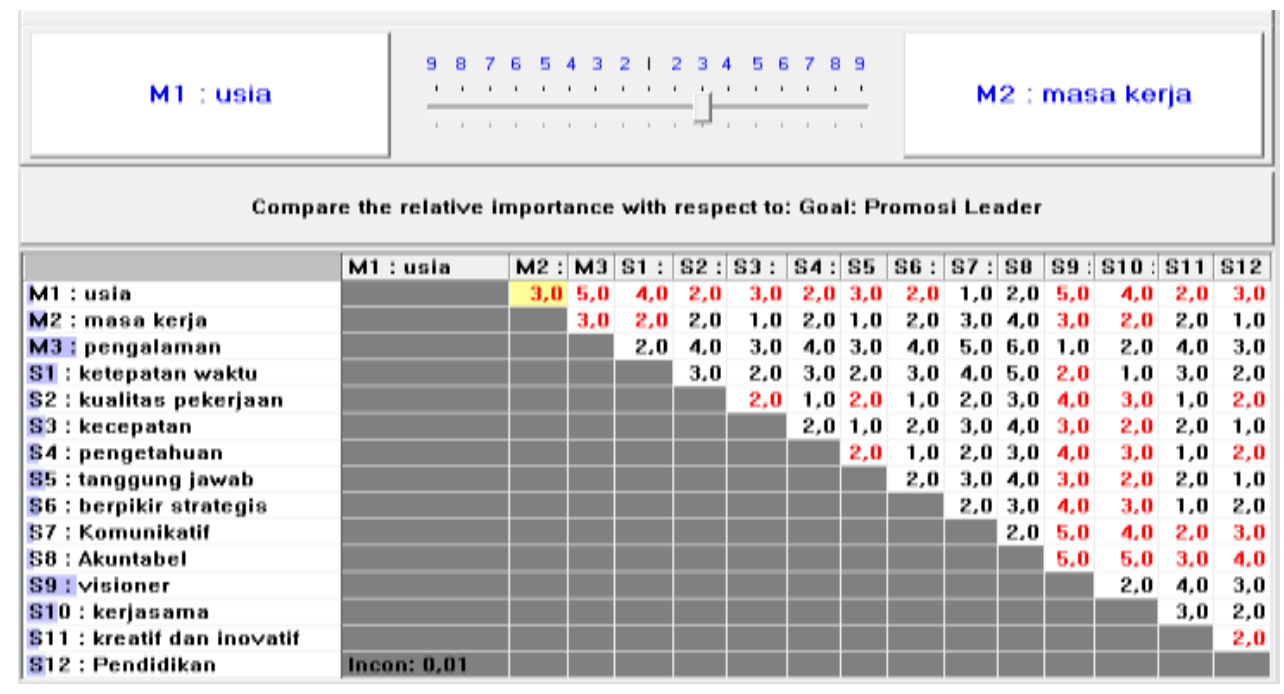

Gambar 3. Nilai Perbandingan Berpasangan Kriteria

b. Normalisasi matriks 
Normalkan data dengan membagi nilai dari elemen dalam matriks berpasangan terhadap total nilai dari kolom untuk mendapatkan nilai eigen vector dengan menggunakan aplikasi expert choice yang ditunjukkan pada gambar 4 .

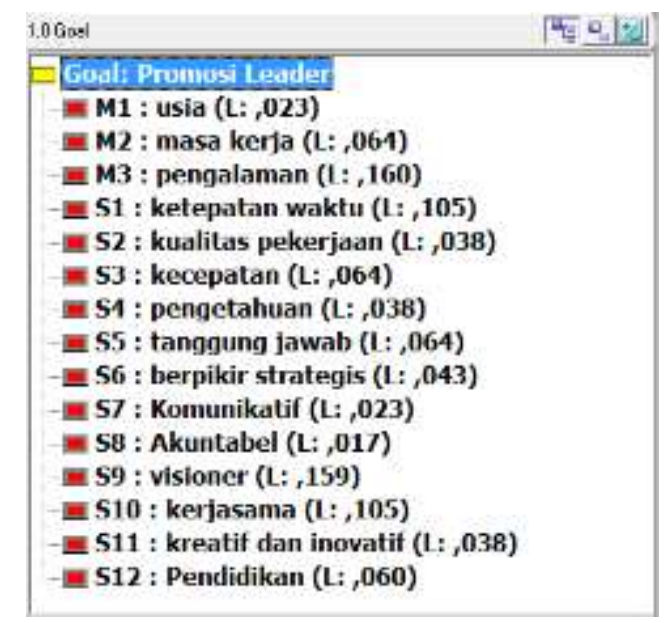

Gambar 4. Hasil Eigen Vector dari tahap Normalisasi Matriks untuk mendapatkan Bobot Kriteria

c. Uji konsistensi

Setelah dilakukan proses perbandingan antara kriteria dalam promosi leader maka akan dilakukan pemeriksaan konsistensi penilaian yaitu dikatakan konsistensi jika nilai consistensi rasio memiliki nilai dibawah dari 0,1 dengan menggunakan aplikasi expert choice. Berdasarkan nilai dari resposnden maka didapat nilai CR yang ditunjukkan pada gambar 5 .
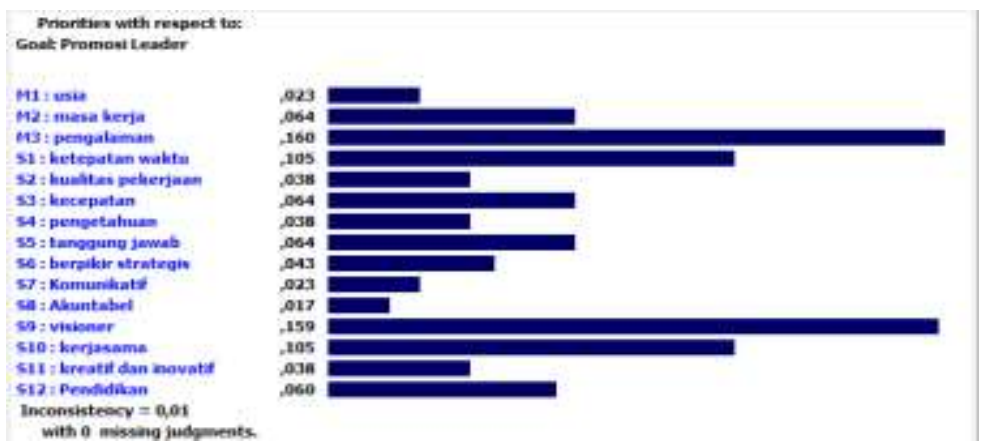

Gambar 5. Prioritas dan Nilai Konsistensi perbandingan kriteria

Berdasarkan data nilai consistensi rasio (CR) yang terdapat gambar 5 dimana setiap kriteria memiliki nilai $\mathrm{CR}<0.1$ maka dapat diambil kesimpulan bahwa preferensi responden adalah konsisten.

\subsection{Perangkingan}

Proses perangkingan dilakukan dengan menerapkan metode Simple Additive Weighting (SAW) dimana bobot perioritas didalam penilaian kinerja crew sebagai pengambilan keputusan untuk pengangkatan leader diambil berdasarkan penerapan metode Analytical Hierarchy Process (AHP) dari gambar 5.

a. Data Rekam Jejak Kinerja Crew

Adapun data rekam jejak kinerja crew dengan menggunakan 5 sampel penilaian kinerja crew dapat dilihat pada tabel 1, penilaian diberikan untuk masing crew untuk semua kriteria dari nilai 1-10.

Tabel 1. Data Penilaian Kinerja Crew

\begin{tabular}{ccccccccccccccccc}
\hline NO & Crew & M1 & M2 & M3 & S1 & S2 & S3 & S4 & S5 & S6 & S7 & S8 & S9 & S10 & S11 & S12 \\
\hline 1 & Crew-01 & 2 & 5 & 3 & 9 & 3 & 4 & 8 & 3 & 2 & 9 & 2 & 7 & 7 & 8 & 6 \\
2 & Crew-02 & 4 & 6 & 2 & 8 & 7 & 5 & 5 & 4 & 3 & 8 & 5 & 4 & 6 & 5 & 7 \\
3 & Crew-03 & 5 & 7 & 5 & 7 & 8 & 6 & 6 & 5 & 4 & 5 & 6 & 3 & 2 & 5 & 6 \\
4 & Crew-04 & 6 & 5 & 8 & 4 & 5 & 5 & 4 & 9 & 8 & 8 & 6 & 5 & 5 & 4 & 8 \\
5 & Crew-05 & 7 & 3 & 9 & 5 & 1 & 5 & 4 & 4 & 4 & 8 & 2 & 2 & 4 & 6 & 7 \\
\hline
\end{tabular}

b. Matrik Keputusan (X)

Data rekam jejak kinerja crew dibuat kedalam bentuk matrik keputusan (X) berdasarkan tabel 1 dengan menggunakan persamaan (2). 


$$
\mathrm{X}=\left|\begin{array}{lllllllllllllll}
2 & 5 & 3 & 9 & 3 & 4 & 8 & 3 & 2 & 9 & 2 & 7 & 7 & 8 & 6 \\
4 & 6 & 2 & 8 & 7 & 5 & 5 & 4 & 3 & 8 & 5 & 4 & 6 & 5 & 7 \\
5 & 7 & 5 & 7 & 8 & 6 & 6 & 5 & 4 & 5 & 6 & 3 & 2 & 5 & 6 \\
6 & 5 & 8 & 4 & 5 & 5 & 4 & 9 & 8 & 8 & 6 & 5 & 5 & 4 & 8 \\
7 & 3 & 9 & 5 & 1 & 5 & 4 & 4 & 4 & 8 & 2 & 2 & 4 & 6 & 7
\end{array}\right|
$$

c. Normalisasi Matrik $\left(\mathrm{r}_{\mathrm{ij}}\right)$

Normalisasi matrik dilakukan dengan cara menghitung nilai rating kinerja ternomalisasi $\left(\mathrm{r}_{\mathrm{ij}}\right)$ dari alternative crew pada kriteria penilaian kinerja crew dengan menggunakan persamaan (3), dimana semua kriteria merupakan bagian dari aktribut benefit.

$$
r_{11}=\frac{2}{\max \{2,4,5,6,7\}}=\frac{2}{7}=0,29
$$

Hasil normalisasi matriks keputusan dapat dilihat pada tabel 2.

Tabel 2. Hasil Normalisasi Matriks Keputusan $\left(\mathrm{r}_{\mathrm{ij}}\right)$

\begin{tabular}{|c|c|c|c|c|c|c|c|c|c|c|c|c|c|c|c|c|}
\hline NO & Crew & M1 & M2 & M3 & S1 & S2 & S3 & S4 & S5 & S6 & S7 & S8 & S9 & S10 & S11 & S12 \\
\hline 1 & Crew-01 & 0,29 & 0,71 & 0,33 & 1,00 & 0,38 & 0,67 & 1,00 & 0,33 & 0,25 & 1,00 & 0,33 & 1,00 & 1,00 & 1,00 & 0,75 \\
\hline 2 & Crew-02 & 0,57 & 0,86 & 0,22 & 0,89 & 0,88 & 0,83 & 0,63 & 0,44 & 0,38 & 0,89 & 0,83 & 0,57 & 0,86 & 0,63 & 0,88 \\
\hline 3 & Crew-03 & 0,71 & 1,00 & 0,56 & 0,78 & 1,00 & 1,00 & 0,75 & 0,56 & 0,50 & 0,56 & 1,00 & 0,43 & 0,29 & 0,63 & 0,75 \\
\hline 4 & Crew-04 & 0,86 & 0,71 & 0,89 & 0,44 & 0,63 & 0,83 & 0,50 & 1,00 & 1,00 & 0,89 & 1,00 & 0,71 & 0,71 & 0,50 & 1,00 \\
\hline 5 & Crew-05 & 1,00 & 0,43 & 1,00 & 0,56 & 0,13 & 0,83 & 0,50 & 0,44 & 0,50 & 0,89 & 0,33 & 0,29 & 0,57 & 0,75 & 0,88 \\
\hline
\end{tabular}

d. Matrik Ternormalisasi (R)

Hasil dari normalisasi matrik $\left(\mathrm{r}_{\mathrm{ij}}\right)$ pada tabel 2, dirubah dalam bentuk matrik ternormalisasi dengan menggunakan persamaan (4).

$$
\mathrm{R}=\left|\begin{array}{ccccccccccccccc}
0,3 & 0,7 & 0,3 & 1 & 0,4 & 0,7 & 1 & 0,3 & 0,3 & 1 & 0,3 & 1 & 1 & 1 & 0,8 \\
0,6 & 0,9 & 0,2 & 0,9 & 0,9 & 0,8 & 0,6 & 0,4 & 0,4 & 0,9 & 0,8 & 0,6 & 0,9 & 0,6 & 0,9 \\
0,7 & 1 & 0,6 & 0,8 & 1 & 1 & 0,8 & 0,6 & 0,5 & 0,6 & 1 & 0,4 & 0,3 & 0,6 & 0,8 \\
0,9 & 0,7 & 0,9 & 0,4 & 0,6 & 0,8 & 0,5 & 1 & 1 & 0,9 & 1 & 0,7 & 0,7 & 0,5 & 1 \\
1 & 0,4 & 1 & 0,6 & 0,1 & 0,8 & 0,5 & 0,4 & 0,5 & 0,9 & 0,3 & 0,3 & 0,6 & 0,8 & 0,9
\end{array}\right|
$$

e. Hasil Nilai Akhir Preferensi (Vi)

Hasil nilai akhir preferensi pada alternatif crew dengan cara menjumlahkan hasil kali antara matriks ternormalisasi (R) pada langkah d dengan nilai bobot preferensi (W) yang ditunjukkan pada gambar 5 dengan menggunakan persamaan (5).

$$
\begin{aligned}
\mathrm{V} 1= & (0,29 \times 0,023)+(0,71 \times 0,064)+(0,33 \times 0,160)+(1 \times 0,105)+(0,38 \times 0,038)+(0,67 \times 1)+(1 \times 0,038) \\
& +(0,33 \times 0,064)+(0,25 \times 0,043)+(1 \times 0,023)+(0,33 \times 0,017)+(1 \times 0,159)+(1 \times 0,105)+(1 \times 0,038) \\
& +(0,75 \times 0,060) \\
= & 0,713
\end{aligned}
$$

Hasil nilai akhir preferensi (Vi) dapat dilihat pada tabel 4.

Tabel 4. Hasil Nilai Preferensi (Vi)

\begin{tabular}{ccc}
\hline NO & Crew & Vi \\
\hline 1 & Crew-01 & 0,713 \\
2 & Crew-02 & 0,644 \\
3 & Crew-03 & 0,635 \\
4 & Crew-04 & 0,762 \\
5 & Crew-05 & 0,608 \\
\hline
\end{tabular}

Hasil perangkingan penilaian kinerja crew yang tertuang didalam Rekam Jejak Kinerja Crew berdasarkan tabel 4 yaitu urutan pertama dimiliki oleh Crew-04 dengan nilai preferensi sebesar 0,762, urutan kedua dimiliki oleh Crew-01 dengan nilai preferensi sebesar 0,713, urutan ketiga dimiliki oleh Crew-03 dengan nilai preferensi sebesar 0,644, urutan keempat dimiliki oleh Crew-03 dengan nilai preferensi sebesar 0,635, dan urutan kelima dimiliki oleh Crew-05 dengan nilai preferensi sebesar 0,608. Berdasrakan nilai akhir preferensi yang diperoleh oleh setiap crew maka yang diberikan rekomendasi untuk diangkat menjadi Leader adalah Crew-04 dengan nilai 0,762. 
JURNAL MEDIA INFORMATIKA BUDIDARMA

Volume 4, Nomor 1, Januari 2020, Page 96-102

ISSN 2614-5278 (media cetak), ISSN 2548-8368 (media online)

Available Online at https://ejurnal.stmik-budidarma.ac.id/index.php/mib

DOI 10.30865/mib.v4i1.1785

\section{KESIMPULAN}

Rekam jejak kinerja crew dijadikan sebagai model sistem pendukung keputusan dengan menerapkan metode AHP dan SAW dapat memberikan rekomendasi pengangkatan leader berdasarkan penilaian kinerja crew yang terekam dalam rekam jejak kinerja crew dilakukan setiap bulan untuk menilai kinerja seorang crew dalam mengerjakan pekerjaan untuk mencapai visi, misi dan tujuan dari perusahaan tersebut dengan menggunakan merit system dan seniority system.

\section{REFERENCES}

[1] Tanti, L., Puspasari, R., \& Triandi, B. (2018, August). Employee Performance Assessment with Profile Matching Method. In 2018 6th International Conference on Cyber and IT Service Management (CITSM) (pp. 1-6). IEEE.

[2] Tanti, L. (2015). Pemilihan Pegawai Berprestasi Berdasar Evaluasi Kinerja Pegawai Dengan Metode SAW. SEMNASTEKNOMEDIA ONLINE, 3(1), 2-2.

[3] Tanti, L. (2015). Monitoring dan Evaluasi Kinerja Pegawai Dalam Pengambilan Keputusan Pemilihan Pegawai Berprestasi. Creative Information Technology Journal, 2(3), 244-255.

[4] Safrizal, S. (2014). Rekam Jejak Dosen Sebagai Model Pengambilan Keputusan Dalam Pemilihan Dosen Berprestasi. Creative Information Technology Journal, 2(1), 65-76.

[5] Animun, J. S. D., Sepang, J., \& Uhing, Y. (2017). ANALISIS PELAKSANAAN PROMOSI JABATAN DAN MUTASI BERDASARKAN PRESTASI KERJA KARYAWAN PADA PT. BANK RAKYAT INDONESIA (PERSERO), Tbk CABANG MANADO. Jurnal EMBA: Jurnal Riset Ekonomi, Manajemen, Bisnis dan Akuntansi, 5(3).

[6] Shintia, A. (2016). Pengaruh Disiplin Kerja dan Penilaian Kinerja Terhadap Kepuasan Kerja Karyawan PT. Pertamina (Persero) UPMS I Medan.

[7] Riccucci, N. M., \& Naff, K. C. (2017). Personnel management in government: Politics and process. Routledge.

[9] Tanti, L., \& Safrizal, S. (2015). Metode AHP Dalam Penilaian Kinerja Sales Promotion Girls (SPG). SEMNASTEKNOMEDIA ONLINE, 3(1), $2-2$.

[10] Santony, J., Amir, F., \& Novita, R. (2019, December). Application of AHP Analysis to Increase Employee Career Paths in Decision Support Systems. In Journal of Physics: Conference Series (Vol. 1339, No. 1, p. 012030). IOP Publishing.

[11] Saaty, T., \& Kułakowski, K. (2016). Axioms of the Analytic Hierarchy Process (AHP) and its Generalization to Dependence and Feedback: The Analytic Network Process (ANP). arXiv preprint arXiv:1605.05777.

[12] Safrizal, S. (2015). PENERIMAAN SISWA BARU (PRAMUGARI) PADA LEMBAGA PENDIDIKAN DAN PELATIHAN PENERBANGAN (STUDI KASUS: LPP PENERBANGAN QLTC). SEMNASTEKNOMEDIA ONLINE, 3(1), 2-2.

[13] Dalle, J., Windarsyah, W., \& Ridho, R. (2018). Decision Support System for Selecting Banjar Restaurant in Banjarmasin City Using Simple Additive Weighting Method. Journal of K6, Education and Management, 1(4), 35-43.

[14] Hidayat, S. W., Bastari, A., Sutrisno, S., \& Suharyo, O. S. (2019). APPLICATION OF FUZZY MULTIPLE CRITERIA DECISION MAKING (MCDM) IN SELECTION OF PROSPECTIVE EMPLOYEES. INTERNATIONAL JOURNAL OF ASRO-STTAL, 10(1), 10-16. 